PATTINGALLOANG

COJurnal Pemikiran Pendidikan dan Penelitian Kesejarahan

\title{
Pengolahan Sagu di Desa Cenning Kecamatan Malangke Barat Kabupaten Luwu Utara, 1982-2017
}

\author{
Umrah Hamid, Muh. Rasyid Ridha, Muh. Saleh Madjid \\ Prodi Pendidikan Sejarah Fakultas Ilmu Sosial Universitas Negeri Makassar, Indonesia \\ umrahhamid8@gmail.com
}

\begin{abstract}
Abstrak
Penelitian ini bertujuan untuk mengetahui Modernisasi Pengolahan Sagu di Desa Cenning Kecamatan Malangke Barat Kabupaten Luwu Utara (1982-2017) dengan mengungkap pengolahan sagu sebelum modernisasi, proses modernisasi pengolahan sagu serta dampak dari modernisasi. Hasil penelitian menunjukkan bahwa pengolahan sagu sebelum adanya modernisasi masih bergantung pada alat-alat tradisional. Modernisasi pada proses pengolahan sagu ditandai dengan penggunaan mesin yang diperkenalkan oleh Muh. Majid pada tahun 1982. Pada proses perkembangannya secara perlahan alat modern menggantikan alat tradisional. Modernisasi memberi dampak pada peningkatan hasil produksi, peningkatan tenaga kerja, dan efisiensi waktu pengolahan. Berdasarkan hasil penelitian dapat disimpulkan bahwa dengan penggunaan teknologi modern pada proses pengolahan sagu lebih efektif dan efisien di banding dengan menggunakan alat-alat tradisional. Penelitian ini menggunakan metodologi penelitian sejarah yang meliputi heuristik yaitu tahapan pengumpulan data, kritik sumber bertujuan menilai dan menentukan sumber, interpretasi yaitu menafsirkan data dan tahap historiografi atau penyajian atau penulisan sejarah. Metode pengumpulan data dilakukan dengan cara penelitian lapangan terdiri dari wawancara (Petani Sagu) dan literatur-literatur yang berhubungan dengan penelitian ini.
\end{abstract}

Kata Kunci: Pengolahan, Sagu, Cenning

\begin{abstract}
This study aims to study the modernization of sago prosessing in the village og Cenning, Malangke Barat Sub-district, West Luwu District (1982-2017). By revealing the processing of sago before modernization, the proccess of medernization and impact of modernization. Research result show that sago processing before modernization still depends on tradisional tools. Modernization in the rocessing of the sagoo is maked by yhe use of machines introduced by the Muh. Majid in 1982. In the process of development slowly modern tools replace traditional tools. Modernization has an impact on increasing production output, increasing labor and processing time efficiency. Baced on the results of the study it can be concluded that the use of modern technology in theprocessing og the sago is more effective and afficient compared to using traditional tools. This research uses historical research methodologies which include heuristics namely the stages of data collection, source criticism aimed at assessing and determining sources, interpretation, namely interpreting data and historiographic stages or presenting or writing history. The data collection method was carried out by means of field research consisting of interviews (sago farmers) and the literature relating to this research.
\end{abstract}

Keywords: Sago, Processing, Cenning

Volume 6 No.3 Juli-September 2019, 109-122|109 


\section{A. Pendahuluan}

Modernisasi pertanian adalah suatu perubahan pengolahan usaha dari yang tradisional ke pertanian yang lebih maju dengan penggunaan teknologi-teknologi baru. Modernisasi dapat diartikan transformasi yaitu perubahan. Dalam artian yang lebih luas transformasi tidak hanya mencakup perubahan yang mencakup perubahan yang terjadi pada bentuk luar, namun pada hakekatnya meliputi bentuk dasar, fungsi, struktur, atau karakteristik suatu kegiatan usaha ekonomi masyarakat. (Munthe, 2007). Kemajuan dan perkembangan pembangunan di bidang apapun tidak dapat dilepas dari kemajuan teknologi. Teknologi baru yang yang diterapkan dalam bidang pertanian selalu dimasukkan untuk menaikkan atau meningkatkan produktifitas terhadap tanah, modal atau tenaga kerja. (Bahri, 1995). Oleh karena itu modernisasi pembangunan pertanian dalam menghasilkan bahan pangan terus dikembangkan, salah satu bahan pangan tersebut yaitu modernisasi dalam pengolahan sagu. Tanaman Sagu merupakan bahan pangan yang telah lama dikenal sebagian masyarakat Indonesia. Daerah-daerah yang termasuk penghasil sagu utama adalah Papua, Papua Barat, Maluku, Maluku Utara, Sulawesi Tenggara, Sulawesi Selatan, Kalimantan Tengah, Kalimantan Barat, Sumatera, Riau dan Nangro Aceh Darussalam. Di daerah-daerah penghasil sagu utama tersebut, keberadaan sagu sangat penting. Bukan hanya karena posisinya sebagai bahan makanan pokok, tetapi juga bagian-bagian dari pohon sagu dapat dimanfaatkan untuk kepentingan di luar domain kuliner. (Lisungan, 2012).

Luwu Utara dikenal sebagai kabupaten penghasil sagu terbesar di Sulawesi Selatan, pada tahun 2017 luas areal lahan sagu mencapai 1,790 Ha dengan hasil produksi 1.960 Ton sedangkan lahan sagu yang ada di Kabupaten Luwu Utara paling besar terdapat di Kecamatan Malangke Barat untuk tahun 2017 luas lahan sagu 1,061 $\mathrm{Ha}$ dengan hasil produksi 1,198 Ton. (Perkebunan, 2017). Namun yang menjadi persoalan sebelum menjadi daerah penghasil sagu, apakah setiap tahunnya luas lahan sagu semakin meningkat atau justru berkurang karena pohon sagu yang ada di Kabupaten Luwu Utara tumbuh secara alamiah, tidak ada upaya dari masyarakat dan pemerintah untuk membudidayakan tanaman sagu. Desa Cenning kecamatan Malangke Barat merupakan salah satu daerah penghasil sagu di Luwu Utara. Sudah sejak dahulu sagu tumbuh subur di Desa Cenning, hal ini dikarenakan banyaknya daerah rawa-rawa sehingga sagu dapat tumbuh subur secara alamiah. Sagu bagi masyarakat Desa Cenning sangat penting karena mereka telah mengenal sagu selama ratusan tahun dan menjadikan sagu makanan pokok selain beras, tidak hanya batang tanaman sagu saja yang dapat dimanfaatkan masyarakat menjadi bahan makanan namun ada beberapa bagian dari pohon sagu yang digunakan masyarakat untuk kepentingan sehari-hari. Daun dari pohon sagu digunakan sebagai atap rumah, pelepah untuk dinding rumah dan ampasnya dapat dimanfaatkan sebagai pulp untuk pembuatan kertas atau pakan ternak. (Batseba, 2000).

Sejak dahulu masyarakat mengolah sagu hanya untuk memenuhi kebutuhan pangan keluarga, hal ini karena Sagu yang dapat tumbuh subur hampir di seluruh daerah di Luwu membuat masyarakat pada saat itu belum menganggap sagu memiliki nilai ekonomis. Modernisasi perngolahan sagu di Desa Cenning ditandai dengan penggunaan mesin pada proses pemarutan. Modernisasi membawa dampak positif maupun negatif bagi kehidupan masyarakat, dengan adanya mesin pengolahan sagu menjadil lebih efisien dibanding menggunakan alat-alat yang masih bersifat tradisional. Perubahan kehidupan sosial ekonomi pada kehidupan masyarakat juga dirasakan seiring dengan adanya perkembangan teknologi. Oleh karena itu penulis tertarik untuk mengkaji bagaimana pengaruh modernisasi ini bagi kehidupan masyarakat khususnya di Desa Cenning. Maka penulis mengangkat judul Modernisasi Pengolahan Sagu di Desa Cenning Kecamatan Malangke Barat Kabupaten Luwu Utara Tahun 1982-2017 


\section{B. Metode Penelitian}

Setiap ilmu mempunyai metode, tanpa metode kumpulan pengetahuan tentang obeek tertentu tidak dapat dikatakan sebagai ilmu, sekalipun masih ada syarat lain. Motode merupakan sebuah cara prosedural untuk membuat dan mengerjakan sesuatu dalam sebuah sistem yang teratur dan tere ncana. Jadi, terdapat prasyarat yang ketat dalam melakukan sebuah penelitian. Dalam kaidah ilmiah, metode berkaitan dengan cara kerja dan prosedur untuk dapat memahami objek yang menjadi sasaran ilmu yang bersangkutan. Metode dalam studi sejarah adalah seperangkat aturan dan prinsip sistematis dalam mengumpulkan sumber-sumber sejarah secara sistematis, menilainya secara kritis dan mengajukannya secara tertulis. Berdasarkan uraian tersebut dapat disimpulkan bahwa metode sejarah merupakan cara atau tehnik dalam merekonstruksikan peristiwa masa lampau melalui empat tahap kerja yaitu heuristik, (pengumpulan sumber), kritik sumber (eksternal/ bahan dan internal/ isi), interpretasi (penafsiran) dan historiografi (penulisan kisah sejarah).

\section{Heuristik}

\section{Sebelum}

menentukan

teknik pengumpulan summber sejarah, petamatama yang perlu dipahami adalah bentuk dari sumber sejarah yang dikumpulkan. Penentuan sumber sejarah akan mempengaruhi tempat (dimana) atau siapa dan cara memperoleh. Pertama, sumber tulisan yakni jejak masa lalu yang mengandung informasi dan bentuk tulisan. Tulisannya dapat berupa informasi primer dan sekunder. Informasi primer biasa dikenal dengan pengetahuan tentang peristiwa dari tangan pertama atau langsung dibuat dengan ketika peristiwa itu terjadi. Sumber primer umumnya berupa arsip, catatan perjalanan, risalah sidang, daftar hadir peserta surat keputusan dan sebagainya.

Sumber sejarah primer yang tertulis dalam sejarah umumnya berupa dokumen. Dokumen tersebut dapat diperoleh pada lembaga -lembaga khusus yang menangani atau menghimpun arsip atau koleksi perorangan yang belum disimpan pada lembaga terkait. Misalnya Arsip Nasional Republik Indonesia dan Perpustakaan Nasional di Jakarta dan di Daerah khusus pengumpulan terakhir, perlu diketahui sejarawan atau peneliti bahwa tidak semua sumber arsip yang dibutuhkan dapat digandakan. Kedua sumber tulisan yakni informasi tentang suatu peristiwa baik yang disampaikan secara turun temurunn maupun langsung dari pelaku sejarah. Penggunaan oral tradision dalam karya penulisan sejarah apabila tidak ada sumber lisan langsung (oral history) maupun tulisan. (Madjid, 2018).

\section{a. Penelitian lapangan}

Penelitian lapangan dimaksudkan untuk mengumpulkan data-data atau sumber primer dengan cara observasi dan wawancara. Metode observasi yaitu pengamatan langsung ke lapangan dimana peneliti dapat melakukan pengamatan langsung terhadap obyek penelitian yakni di Desa Cenning. Sedangkan metode wawancara dengan melakukan tanya jawab dengan informan yaitu Rasmi, Baso, $\mathbf{H}$. Sinakati. Maslita, Irwan dan beberapa orang lainnya terkait ataupun terlibat dengan masalah yang diteliti sehingga dapat diperoleh informasi atau data primer. Adapun hasil wawancara dapat direkam maupun dicatat untuk selanjutnya digunakan dalam penyusunan .

\section{b. Penelitian Pustaka}

Penelitian pustaka dilakukan untuk menunjang penelitian lapangan. Penelitan pustaka dapat dilakukan dengan mengumpulkan sumber berupa buku-buku, dokumen Laporan, hasil penelitian maupun artikel ilmiah yang berkaitan dengan Modernisasi Pengolahan Sagu. Adapun tempat untuk mendapatkan sumber tersebut diperoleh dari perpustakaan wilayah provinsi Sulawesi selatan, Badan Pelestarian Nilai Budaya, perpustakaan jurusan pendidikan sejarah UNM, perpustakaan umum Universitas Negeri Makassar, Perpustakaan Universitas Hasanuddin dan Kantor Dinas 
Perkebunan dan Kehutanan Luwu Utara. (Sejarah, 2013).

\section{Kritik}

Dalam usaha mencari kebenaran, sejarawan dihadapkan dengan kebutuhaan untuk membedakan apa yang benar, apa yang tidak benar, apa yang mungkin dan apa yang meragukan atau mustahil. Sumbersumber yang telah dikumpulkan baik berupa sumber tertulis, sumber benda maupun lisan kemudian diverifikasi atau diuji melalui serangkaian kritik, baik yang bersifat ekstern maupun intern.

Kritik intern lakukan untuk menilai kelayakanatau kredibilitas sumber. Kredibilitas sumber biasanya mengacu pada kemampuan sumber untuk mengungkap kebenaran suatu peristiwa sejarah. Sedangkan kritik ekstern dilakukan untuk mengetahui sejauh mana keabsahan atau autensitas sumber. Kritik terhadap autensitas sumber tersebut misalnya dengan melakukan pengecekan tanggal penerbitan dokumen, pengecekan bahan yang berupa kertas atau tinta apakah cocok dengan masa dimana bahan semacam itu bisa digunakan atau di produksi. Memastikan sumber apakah termasuk sumber asli atau salinan. (M Dien Madjid, 2014).

\section{Interpretasi}

Pada tahap ini sumber atau data sejarah yang telah diseleksi dapat digunakan sebagai sumber atau bahan penulisan sejarah, namun sumber tersebut masih harus dilakukan penelitian lebih lanjut yang dikenal dengan interpretasi (penafsiran). Dalam tahap ini penulis dituntut untuk bisa menghasilkan interpretasi yang tidak memihak dan sesuai dengan kebaran fakta yang ada karena unsure subjektivitas terkadang dapat mempengaruhi isi penulisan. Hal ini dimaksud untuk memberi arti terhadap aspek yang diteliti, mengaitkan fakta yang satu dengan fakta lainnya agar ditemukan kesimpulan penulisan ilmiah.

\section{Historiografi}

Tahap ini merupakan tahap terakhir dalam penelitian sejarah. Pada tahap ini peneliti akan menuliskan peristiwa sejarah tersebut dalam sebuah tulisan yang dalam penulisan, pemaparan dan pelaporan menggunakan tata cara tertentu. Dimana dalam hal ini, penelitian yang peneliti lakukan adalah penelitian dengan kajian kepustakaan dan lapangan. Penulisan sejarah merupakan proses penjelasan dari semua kegiatan dalam proses penelitian sejarah. (Syamsuddin, 2012). Tahap penulisan sejarah bukan hanya rangkaian fakta saja, namun sejarah merupakan sebuah cerita, cerita yang dimaksudkan ialah penghubungan atara kenyataan yang sudah menjadi keyataan peristiwa, dan suatu pengertian bulat dalam jiwa manusia atau pemberian tafsiran interpretasi terhadap kejadian tersebut. Pada tahap ini penulis mencoba untuk menggambarkan hasil penelitiannya. Dalam hal ini pada penelitian tentang Modernisasi Pengolahan Sagu di Desa Cenning Kecamatan Malangke Barat Kabupaten Luwu Utara.

\section{Tinjauan Umum Penelitian}

Kabupaten Luwu Utara merupakan kabupeten pemekaran dari kabupaten Luwu Raya pada tahun 1999 di bentuk berdasarkan UU No.19 tahun 1999. Kabupaten Luwu utara berbatasan dengan beberapa kabupaten. Di sebelah utara berbatasan dengan Sulawesi Tengah, di sebelah barat berbatasan dengan Sulawesi Barat dan Tana Toraja dan di sebelah timur berbatasan dengan kabupaten Luwu dan teluk Bone. Secara astronomis Kabupaten Luwu Utara terletak antara $01^{\circ} 53^{\prime} 1$ ' $-02^{\circ}$ $55^{\prime} 36^{\prime \prime}$ LS dan $119^{\circ} 47^{\prime} 46^{\prime \prime}-120^{\circ} 37^{\prime} 44^{\prime \prime}$ BT

Wilayah administratif Kabupaten Luwu Utara terbagi manjadi 12 wilayah kecamatan. Kabupaten Luwu Utara pada dasarnya dapadibagi menjadi 2 wilayah berdasarkan topografinya yaitu wilayah daratan sebanyak kecamatan dengan ketinggian 15-70 meter di atas permukaan laut dan daratan tinggi sebanyak 3 kecamatan dengan ketinggian di atas 1.000 meter di atas permukaan laut. Wilayah administratif Kabupaten Luwu Utara terbagi manjadi 12 wilayah kecamatan. Lokasi yang dipilih peneliti untuk 
melakukan penelitian adalah kecamatan Malangke Barat tepatnnya di Desa Cenning. Malangke Barat dulu satu kesatuan dengan kecamatan di sebelahnya yaitu Kecamatan Malangke namun dimekarkan pada tahun 1998. Kecamatan Malangke Barat secara administratif memiliki beberapa desa yaitu: Pombakka, Welawi, Pengkajoang, Pao, Waetuwo, Arusu, Pembuniang, Cenning, Wara, Limbong wara, Kalitata, Pole jiwa, Baku-baku.

Desa Cenning merupakan desa fokus penelitian penulis. Secara astronomis terletak pada 120.279534 LS/LU -2.780624. Di sebelah utara berbatasan dengan lembang-lembang, sebelah selatan berbatasan dengan Pombakka, di sebelah timur berbatasan dengan Pembuniang, dan di sebelah barat berbatasan dengan Wara. Jarak Desa cenning dari ibu kota kecamatan adalah $7 \mathrm{Km}$, jarak ke kota kabupaten adalah $60 \mathrm{Km}$, dan jarak dari ibu kota provinsi adalah $535 \mathrm{Km}$. Desa Cenning terbagi atas 6 dusun di antaranya Dusun Salobongko, Dusun Tokkatapi, Dusun Tuara, Dusun To'baka, Dusun Urukumpang dan Dusun Salulemo.

Jumlah Penduduk di Desa Cenning pada tahun 2017 berjumlah 4.075 jiwa lakilaki berjumlah 2.074 jiwa dan perempuan berjumlah 2001 jiwa. Penduduk dengan usia 0-17 tahun berjumlah 1.010 jiwa, usia 18-55 berjumlah 2.272 jiwa dan usia 55 tahun keatas berjumlah 1.209 jiwa. Penduduk Cenning adalah penduduk yang heterogen selain terdapat penduduk asli terdapat pula penduduk pendatang yang tinggal di Desa Cenning, seperti dari daerah Wajo, Bone, Soppeng, Sidrap, Palopo, dan Belopa.(Jumadil, 2019). Mata pencaharian merupakan perekerjaan pokok yang menjadi sumber penghidupan. Mata pencaharian masyarakat Desa Cenning adalah pertanian, perkebunan, nelayan, peternak dan pengolah sagu. Padi juga merupakan salah satu komoditi yang dibudidayakan oleh masyarakat. Padi sebagai sumber makanan pokok sehingga hampir seluruh dusun di Desa Cenning terdapat lahan sawah kecuali di Dusun Tuara. Tanah di Desa Cenning yang relatif rendah pemanfaatan lahan untuk lahan persawahan dianggap sebagai pilihan yang tepat.

Pada abad ke-17 Malangke menjadi pusat penyebaran agama Islam di kerajaan Luwu, seluruh masyarakat di Luwu memeluk agama islam termasuk masyarakat Cenning yang memang merupakan daerah kekuasaan kerajaan Luwu. Agama islam bertahan hingga sekarang, masyarakat Cenning sangat menjunjung tinggi ajaran agama islam hal ini dapat dilihat dari kebiasaan masyarakat separti shalat berjamaan di mesjid baik perempuan ataupun laki-laki. Sebelum islam masuk di kerajaan Luwu, masyarakat Luwu telah memiliki kepercayaan yaitu animisme dan dinamisme. Animisme adalah kepercayaan yang menganggap bahwa setiap benda mempunyai roh. Sedangkan dinamisme adalah kepercayaan yang menganggap bahwa segala sesuatu mempunyai tenaga dan kekuatan yang dapat mempengaruhi kehidupan manusia. Namun setelah islam datang, kepercayaan tersebut telah punah dan di gantikan dengan agama Islam. Selain agama islam terdapat juga beberapa masyarakat yang menganut agama kristen, agama kristen di bawa oleh orang Toraja yang merantau ke Desa Cenning.

\section{Pembahasan}

Sagu tumbuh di daerah-daerah rawa yang berair tawar atau daerah rawa yang bergambut dan di daerah-daerah sepanjang aliran sungai, sekitar sumber air atau di hutan-hutan rawa yang kadar garamnya tidak terlalu tinggi. Lingkungan yang baik untuk pertumbuhan sagu adalah adalah daerah yang berlumpur dimana akar napas tidak terendam, kaya mineral organik air tanah berwarna coklat dan bereaksi agak asam. (Pangolangi, 1991). Di Desa Cenning Sagu tumbuh secara alamiah di sepanjang pinggiran sungai Barere dan Salobatu yang ada di Desa Cenning. Sagu merupakan makanan pengganti beras ketika masa paceklik, kondisi persawahan yang hanya bisa ditanami satahun sekali seringkali membuat hasil pertanian rakyat tidak 
mampu untuk memenuhi kebutuhan pangan keluarga. Sehingga untuk memenuhi kebutuhan pangan sehari-hari, masyarakat Desa Cenning mengolah batang sagu untuk dijadikan tawaro. Untuk beberapa masyarakat yang tidak memiliki lahan sawah, tawaro merupakan makanan pokok bagi mereka. Hal inilah yang menyebabkan adanya anggapan bahwa masyarakat yang mengkonsumsi sagu adalah masyarakat yang kurang mampu karena sagu dianggap sebagai makanan kedua setelah beras.

Pertanian adalah pengolahan tanaman dan lingkungannya agar memberikan suatu produk. Sedang dalam artian luas pertanian adalah pengolahan tanaman, ternak, ikan dan lingkungannya agar memberikan suatu produk. Merujuk dari pengertian pertanian maka dapat dikatakan masyarakat Cenning adalah petani sagu karena kegiatan yang dilakukan bukan hanya pada kegiatan pengolahan namun juga pada kegiatan penanaman meskipun penanaman dilakukan tidak rutin seperti halnya tanaman pertanian lainnya. Penanaman sagu dilakukan jika antara rapu tawaro atau rumpun sagu terdapat lahan kosong maka akan dilakukan penanaman.

\section{Pengolahan Sagu Tradisional}

Proses pengolahan sagu sacara tradisional disebut massampe dan petani sagu disebut sebagai passampe hal ini karena alat utama yang digunakan untuk menokok batang sagu yang disebut sampe. Setelah sampe sudah tidak digunakan lagi, istilah massampe tergantikan dengan istilah mapperra hal ini didasari oleh kegiatan memeras empulur sagu yang dilakukan petani sagu. namun untuk petani sagu sendiri masih disebut passampe karena masyarakat sudah terbiasa dengan istilah tersebut.

Pengetahuan masyarakat Desa Cenning tentang sistem pertanian tradisional mereka dapatkan secara turun temurun sehingga pengetahuan tersebut diwariskan dari generasi ke generasi. Begitu pula dengan Pengetahuan masyarakat mengenai sagu mulai dari pemanfaatan sagu, ciri-ciri sagu siap panen hingga cara pengolahan. Pohon sagu yang dapat dimanfaatkan adalah pohon sagu yang telah berusia 5-13 tahun ditandai dengan daun pohon yang semakin rimbun dan telah berbuah yang biasa disebut dengan tawaro matase'. Ciri-ciri sagu siap panen pada umumnya dapat dilihat dari perubahan yang terjadi pada pucuk, dan batang. Umumnya sagu siap panen menjelang pembentukan primordia bunga atau kuncup bunga sudah mulai muuncul tetapi belum mekar. Pada saat tersebut bunga terakhir yang keluar mempunyai jarak yang berbeda dengan daun sebelumnya dan daun terkahir juga berbeda dengan daun sebelumnya yaitu lebih tegak dan ukurannya lebih kecil.

Petani sagu di Cenning mengetahui ciriciri sagu siap panen dapat dilihat dari bentuk daun yang paling atas. Sagu yang sudah siap panen adalah sagu yang daunnya telah berjarak antara satu ruas daun ke ruas yang lain dan pelepah dauh yang menjadi pendek bila dibandingkan dengan pelepah sebelumnya. Sagu yang sudah terlalu tua sudah tidak diolah lagi karena kandungan aci dalam batang telah berkurang. Sagu yang sudah tua dapat diliat dari kuncup bungan sagu yang telah mekar dan bercabang. (Arsyad, 2019). Proses penebangan pohon sagu didahului dengan kegiatan penebasan semak belukar atau rumput liar di sekitar pohon sagu dengan menggunakan parang panjang. Penebasan ini dimaksudkan agar proses penebangan dan pengambilan batang sagu tidak mengalami hambatan. Penebangan pohon sagu dilakukan dengan menggunakan kampak atau. Dengan beberapa kali ayunan, biasanya pohon sagu akan tumbang. Hal ini disebabkan batang sagu memang relatif lunak dibandingkan pohon biasa. Setelah pohon sagu tumbang, pelepah dan daun pohon sagu akan dipangkas kemudian batang pohon sagu dibagi menjadi beberapa bagian dengan panjang setengan meter setiap bagiannya.

Batang merupakan bagian yang terpenting karena merupakan gudang penyimpanan aci atau karbohidrat. Ukuran batang sagu berbeda-beda tergantung jenis, umur dan lingkungan atau habitat pertumbuhannya. Pada umur 5-13 tahun 
tinggi batang bebas daun sekitar 3-16 m, bahkan dapat mencapai $20 \mathrm{~m}$. Dalam proses pengolahan terdiri dari beberapa tahap:

\section{a. Makkunisi'(Menguliti)}

Pohon sagu yang sudah ditebang biasanya dibagi menjadi beberapa bagian agar lebih mudah diangkut ke tempat pegolahan. Jika pohon sagu berada di seberang tempat pengolahan maka batang sagu tidak akan dibagi karena batang sagu yang utuh akan diikat menggunakan tali kemudian dihanyutkan agar batang sagu lebih mudah dibawa ke tempat pengolahan yang ada di seberang sungai. Setelah batang sagu sampai ke tempat pengolahan, batang sagu akan dipisahkan dengan kulit luar, kemudian dibagi menjadi beberapa bagian yang lebih kecil agar lebih mudah diolah.

\section{b. Massampe (Menokok) Atau Mapparu (Memarut)}

Proses massampe atau menokok merupakan proses penghancuran batang sagu menjadi serat yang lebih halus agar proses pemisahan antara serat dan aci lebih mudah dilakukan. Proses ini dilakukan dengan menggunakan alat tradisional yang di sebut sampe. Proses massampe di lakukan dengan cara membagi dua batang sagu kemudian empulur dipukul-pukul agar empulur di hancurkan. Setelah sampe sudah tidak digunakan lagi, proses penghancuran empulur sagu beralih ke penggunaan paru' Untuk mengolah sagu, sampe adalah alat pertama yang digunakan untuk metokok batang sagu. Kemudian awal tahun 1970 masyarakat mulai menggunakan parut untuk mencacah batang sagu. Proses mapparu di lakukan oleh satu orang dengan cara medorong batang sagu yang telah di potong dengan ukuran yang lebih kecil secara satu arah.

\section{c. Maperra'(Memeras)}

Proses selanjutnya adalah mapperra. Empulur yang telah diparut atau ditokok akan berwarna kecoklatan dan apabila dibiarkan cukup lama aci yang dihasilkan mutunya kurang baik karena aci mengalami oksidasi oleh karena itu empulur yang disampe atau yang diparut harus habis dalam satu hari pengolahan. Hasil parutan dibawah ke tempet pemerasan dan wadah yang digunakan untuk menyimpan empulur sagu dan aci sagu yang akan diendapkan adalah perahu. Ukuran perahu biasanya berbeda, perahu yang digunakan untuk pengendapan (lopi tawaro) biasanya lebih besar dibanding perahu untuk wadah empulur sagu (lopi saraing) yang belum diolah. proses pemisahan ini dilakukan dengan cara meremas-remas empulur sagu agar lebih mudah diperas kemudian dengan terus menyiram air agar proses pemisahan dapat dilakukan dengan cepat.

Lopi saraing disanggah dengan kayu agar posisinya lebih tinggi dibanding lopi tawaro sehingga lebih mudah mengalirkan aci sagu ke lopi tawaro. Pada bagian ujung lopi saraing diberi penapis berupa kain tipis agar ampas tidak turun ke lopi tawaro pada saat proses penyiraman dilakukan.Air yang digunakan untuk menyiram adalah air dengan kualitas bagus agar aci sagu yang dihasilkan berwarnah putih, air ini diperoleh dari sungai yang diambil menggunakan penimbah atau Pattimpa. Setelah proses pemerasan dilakuakn, aci sagu diendapakan hingga lopi tawaro penuh.

\section{d. Maddoko (Membungkus)}

Madokko atau proses pemungkusan Aci dengan menggunakan anyaman daun sagu. Aci yang diperoleh dari cara ekstraksi tradisional ini berupa aci basah dan disimpan dalam anyaman daun sagu yang disebut balabba. Ukuran dan bentuk balabba bervariasi dalam satu balabba berat sagu 5-8 Kg. Jika selama penyimpanan kelembaban balabba terjaga dengan baik makan sagu akan tahan hingga 4 bulan. Kelembaban dapat dipelihara dengan cara penyiraman. Karena sagu ini kondisinya lembab saat penyimpanan, maka pasa permukaan saring ditumbuhi cendawan dan kamir yang dapat mengakibatkan terjadinya proses fermentasi yang ditandai dengan keluarnya bau asam.

Proses maddoko dilakukan ketika lopi tawaro telah penuh atau ketika proses pengolahan sagu sudah dianggap cukup. Maddoko dilakukan oleh 2 orang pekerja dan satu orang yang bertugas untuk 
menganyam balabba. Berat satu balabba berkisar 5-7 Kg, untuk satu batang sagu mampu mengasilkan 100 balabbe. (Baso, 2019).

\section{Proses Modernisasi}

Pada mulanya pertanian bergantung pada sumber daya alam, keterampilan, pengetahuan, keterampilan dan institusi lokal. Sistem-sistem pertanian yang bermacam-macam dan khas setempat telah berkembang melalui proses mencoba-coba yang panjang dimana akhirnya ditemukan keseimbangan antara masyarakat dan basis sumber dayanya. Biasanya, produksi ditujukan pada keluarga dan masyarakat substensi. Cara kerjanya sama antar anggota keluarga masyarakat telah dikembangkan dengan baik. Sistem pertanian tradisional terus dikembangkan dalam suatu interaksi yang konstan dengan budaya dan ekologi lokal. Ketika kondisi berubah, misal karena pertumbuhan jumlah penduduk atau pengaruh nilai-nilai asing, sistem pertanian juga mengalami perubahan. (Reijentjes, 2014). Taksonomi teknologi dalam bidang produksi pertanian sering dikaitkan dengan dua jenis teknologi, yaitu: teknologi mekanis untuk menghemat tenaga kerja dan teknologi biologis dan kimiawi untuk menghemat tanah. Teknologi mekanis sengaja dirancang untuk mensubstitusi (mengganti) faktor produksi tenaga kerja dengan mesin. Sebenarnya, tenaga kerja telah disubstitusi dengan tanah karena mampu mengolah lahan lebih luas dibandingkan sebelumnya . Sedangkan teknologi biologis dan kimiawi tercipta dan tersebar luas untuk mengganti kelangkaan sumber daya lahan dengan pupuk dan bibit unggul. (Bustanul, 2001). Untuk peningkatan hasil pangan tentunya harus dibarengi dengan alat-alat produksi yang lebih modern. Banyak sistem pertanian tradisional yang berlangsung dan bertahan selama berabad-abad dalam kemampuannya untuk mempertahankan tingkat produksi yang stabil dan terus menerus.

Lahan sagu di Desa Cenning sangat luas, seluruh pinggiran sungai dipenuhi dengan tanaman sagu yang tumbuh subur. Tanaman sagu yang melimpah inilah yang kemudian dimanfaatkan masyarakat untuk dijadikan pundi-pundi rupiah. Awal tahun 1970 masyarakat Cenning mulai mengolah sagu untuk dijual ke daerah Tolemo Kabupaten Luwu dengan harga Rp. 25-Rp. 50 per bungkus (balebbe). Untuk mengangkut hasil olahan sagu,petani sagu menggunakan perahu kayu atau katinti dianggap cukup sulit karena petani sagu masih menggunakan dayung untuk menggerakkan perahunya. Namun demikian petani sagu tidak mempunyai pilihan lain karena untuk melakukan perjalanan darat masih sulit untuk diakses serta tidak ada kendaraan yang dapat digunakan serta kondisi jalan yang rusak.Untuk daerah sekitar Malangke masyarakat menjual hasil olahannya ke pasar-pasar Ibu kota kecamatan karena tidak semua daerah di Malangke ditumbuhi sagu jadi hal ini merupakan keuntungan bagi petani sagu untuk menjual olahan sagunya ke pasar-pasar tradisional. (Masi', 2019).

Pengolahan sagu menggunakan sampe atau paru' cukup menyulitkan masyarakat karena untuk mengolah sagu dalam satu batangnya membutuhkan waktu 3-5 hari hal ini terjadi karena alat yang digunakan masih sederhana, batang pohon sagu yang akan diolah memiliki panjang 10-20 meter serta untuk memeras empulur sagu, sangat bergantung pada kondisi air sungai. Jika air sungai keruh maka hasil olahan akan berwarna kuning atau bahkan kecoklatan, hal ini tentu berpengaruh pada kualitas sagu dan juga harga sagu. Pengolahan sagu tradisional berlangsung cukup lama di Desa Cenning hal ini disebabkan oleh beberapa faktor yaitu:

a. Kurangnya pengetahuan masyarakat akan perkembangan teknologi alat pertanian sehingga mereka beranggapan bahwa alat yang mereka gunakan adalah alat yang lebih efisien.

b. Sulitnya akses masyarakat untuk ke kota sehingga petani ketinggalan dalam hal informasi.

c. Kurangnya modal yang dimiliki masyarakat sehingga petani belum 
mampu memenuhi kebutuhan alat-alat pertanian modern.

d. Kurangnya peran dari pemerintah untuk mengadakan bantuan kepada petani sagu dalam hal pengadaan mesin pengolahan.

e. Pernintaan sagu masih terbatas sehingga petani merasa masih mampu menyediakan permintaan pasar meski dengan penggunaan alat-alat sederhana.

Masuknya modernisasi pertama kali di Desa Cenning pada tahun 1982 berupa penggunaan mesin yang pertama kali diperkenalkan oleh bapak Muh. Majid yang merupakan kepala Desa Cenning pada saat itu, mesin itu kemudian diserahkan kepada bapak Masi' dan bapak Baso untuk digunakan mengolah sagu dengan sistem bagi hasil. Mesin pertama yang digunakan dengan merek Giandong atau biasa di sebut gandong oleh masyarakat Desa Cenning . Mesin tersebut berkapasitas 7,5 PK yang dibeli di Kota Palopo . Penggunaan mesin pertama kali didasarkan karena ada beberapa desa di sekitar Desa Cenning seperti Desa Takalalla dan Desa Welawi yang telah lebih dulu menggunakan mesin hal inilah yang membuat bapak Muh. Majid berinisiatif membeli mesin di Palopo.

Selain mesin, parut merupakan salah satu bagian penting dalam mesin pengolah sagu, parut yang digunakan bapak Masi' adalah parut yang dibuat dengan menggunakan paku tembok atau terali sebagai gerigi untuk memudahkan proses penghancuran. Parut yang digunakan untuk pengolahan sagu masih dibuat secara manual, hal ini disebabkan karena belum adanya parut sagu yang dijual dipasaran terutama di Palopo yang menjadi tempat masyarakata Cenning membeli alat-alat pertanian. Setelah bapak Muh. Majid, ada beberapa masyarakat yang ikut menggunakan mesin dalam pengolahan sagunya seperti Hamid pada tahun 1985, Jurlis dan H. Sinakati tahun 1984 . Selanjutnya dengan kemudakan yang diperoleh dengan adanya mesin, hampir seluruh masyarakat kemudian beralih menggunakan mesin dalam pengolahan sagu. adanya teknologi ini tentunya diharapkan dapat meningkatkan kualitas hasil olahan maupun pendapatan masyarakat.

Setelah tahun 1982 yang ditandai dengan penggunaan mesin, pengolahan sagu belum mengalami perubahan yang signifikan. yang berbeda hanya pada penggunaan mesin untuk menggerakkan parut. Tempat pengolahan masih tetap dilakukan dipinggir sungai namun proses pemarutan tidak lagi dilakukan di dekat rapu' tawaro melainkan dilakukan di dekat tempat pemerasan empulur sagu. Penggunaan mesin untuk parut tentunya memberikan kemudahan bagi petani sagu.

Perubahan yang paling dirasakan petani ketika tahun 2002 mulai digunakan mesin untuk memompa air. Air yang digunakan untuk menyiram air tidak lagi diambil dari air sungai melainkan dari air dalam tanah yang di sedot menggunakan mesin pompa air atau biasa disebut alkon oleh masyarakat. Mesin pemompa air pertama kali diperkenalkan oleh Ambe' Kallacong yang merupakan perantau dari Tolemo, mesin yang digunakan untuk memompa air sama dengan mesin yang di gunakan untuk menggerakkan parut yaitu bermerek giandong dengan dengan kepasitas 7,5 Pk. (Jurlis, 2019). Pengolahan sagu pada tahun 2002 menngalami peningkatan karena pengolahan tidak lagi dilakukan di pinggir sungai namun berpindah ke daerah yang lebih tinggi meskipun masih di sekitaran sungai. Proses penyiraman tidak lagi dilakukan dengan cara manual melainkan mesin sehingga proses pengolahan semakin cepat. Dampak Modernisasi Pengolahan Sagu

\section{Dampak Modernisasi}

Perubahann teknologi pada masyarakat memberi dampak positif maupun dampak negatif. Perubahan-perubahan yang terjadi dapat dilihat dengan mencermati kehidupan sosial-budaya dan ekonomi masyarakat sebelum adanya modernisasi maupun setelah adanya modernisasi.

\section{a. Sosial Budaya}




\begin{abstract}
Perubahan sosial adalah gejala perubahan dalam lembaga-lembaga kemasyarakatan yang mempengaruhi sistem sosialnya, termasuk dalam perubahanperubahan dalam nilai-nilai, sikap-sikap dan perilaku diantara kelompok-kelompok didalam suatu masyarakat. Perubahan sosial yang terjadi cenderung terjadi dari tahap sederhana ke tahap lebih kompleks,dari tahap masyarakat sederhana (homogen) ke masyarakat yang lebih kompleks (heterogen). Perubahan sosial juga sangat berhubungan dengan pembangunan yang terjadi. (S, 2003). Kehidupan masyarakat sebelum adanya teknologi identik dengan kata tradisional, masuknya alat-alat modern sedikit banyaknya memberi dampak bagi kehidupan masyarakat di pedesaan. Baik berupa dampak positif maupun dampak negatif.
\end{abstract}

\section{1) Perubahan Pola Pikir}

Modernisasi dapat diartikan sebagai proses perubahan corak kehidupan masyarakat yang tradisional menjadi masyarakat yang modern terutama yang berkaitan dengan teknologi dan organisasi sosial. Teori modernisasi dibangun di atas asumsi bahwa perubahan sosial merupakan gerakan searah, progresif dan berlangsung perlahan-lahan yang membawa masyarakat dari tahap primitif kepada keadaan yang lebih maju.

Masuknya modernisasi pertanian membawa pengaruh terhadap pola pikir masyarakat. Pola tersebut tidak hanya sebatas pengetahuan terhadap ilmu pengetahuan dan teknologi dan penerapannya dalam kegiatan pertanian melainkan secara luas membuat masyarakat mampu berfikir lebih maju, menerima perubahan dan dinamis mengikuti perkembangan zaman.

Seperti halnya petani di Desa Cenning, petani mampu beradaptasi dan dinamis menerima perubahan teknologi. Masyarakat tidak terkungkung dalam keterbatasan yang telah ada sejak dahulu. Bahkan masyarakat menyambut baik teknologi yang ada karena dengan teknologi kegiatan pengolahan mereka lebih mudah.

\section{2) Berdampak Terhadap Tenaga Kerja}

Sektor pertanian sangat berperan dalam penyerapan tenaga kerja di pedesaan. Sehingga sebagian besar mesyarakat bekerja di sektor pertanian. Pertanian merupakan satu bentuk usaha yang dilakukan oleh masyarakat tertama masyarakat pesesaan dengan memanfaatkan sumber saya modal dan sumber daya alam. Sistem dan bentuk pendidikan yang umum dikenal di masyarakat utamanya pada masyarakat pedesaan yaitu pendidikan yang ditempuh melalui jalur sekolah. Dan sistem pendidikan itulah yang disebut pendidikan formal sedangkan sistem pendidikan lainnya yaitu cara seseorang memperoleh pengetahuan atau ilmu pengetahuan yang diperoleh seseorang beranjak dari satu pengalaman dan mengikuti pelatihan sesuai dengan minat dan bakat seseorang yang bersangkutan.

Sehubungan dengan lapangan kerja yang dominan tersedia di Desa Cenning adalah pada sektor pertanian, maka sistem modernisasi pertanian belum secara langsung mempengaruhi pendidikan tenaga kerja yang dibutuhkan terutama pendidikan formal. Hal ini kerena keahlian yang dimiliki petani dalam mengolah lahan mereka peroleh secara turun-temurun. Namun demikian, petani sagu umumnya telah menyekolahkan anak-anak mereka ke pendidikan formal, dengan harapan bahwa pendidikan formal dapat memperbaiki nasib mereka di masa depan.

Peluang kerja merupakan hubungan antara angkatan kerja dengan kemampuan penyerapan tenaga kerja. Pertambahan angkatan kerja harus diimbangi investasi yang dapat menciptakan peluang kerja, dengan demikina dapar menyerap tenaga kerja. Perubahan sistem pengolahan sagu di Desa Cenning juga telah berdampak pada ketersediaan tenaga kerja. Dengan perubahan dari sistem tradisional ke modern dapat di katakan telah menambah lapangan kerja bagi tenaga kerja. Dengan cara tradisional pengolahan dilakukan sangat lambat sehingga hanya 2-3 orang saja yang bekerja dalam satu kelompok kerja, hal ini 
dimungkinkan oleh kerena kebanyakan tenaga kerja mampu melakukan dua pekerjaan sekaligus, seperti sesorang pemarut dapat juga menimba atau mengangkat saraing ke tempat pengolahan dan mereka juga beranggapan bahwa semakin banyak orang yang bekerja dalam satu kelompok kerja maka pembagian hasil yang diperoleh dibagi ke banyak orang. Berbeda dengan pengolahan sagu modern, tenaga kerja yang dibutuhkan meningkat kerena proses produksi cepat sehingga membutuhkan tenaga kerja yang banyak. Hal ini di mungkinkan karena setiap tenaga kerja tidak dapat melakukan dua pekerjaan sekaligus, seperti pemarut tidak dapat mengupas batang secara sekaligus.

\section{3) Budaya Gotong Royong}

Gotong royong merupakan salah satu ciri khas bangsa Indonesia. Gotong royong adalah suatu kegiatan yang dilakukan secara bersama-sama dan bersifat suka rela agar kegiatan yang dikerjakan dapat berjalan dengan lancar. Di dalam masyarakat tumbuh dan berkembang bentuk-bentuk kerja sama yang di sebut "tolong menolong". Bentuk gotong royong tolong menolong disini pada hakekatnya dilandasi spontanitas atau pamrih. Seperti misalnya kita kenal bermacam-macam kegiatan gotong royong tolong menolong yang ada di masyarakat yaitu tolong menolong dalam aktivitas rumah tangga maupun dalam aktivitas sehari-hari. (Suwondo, 1983) Di Desa Cenning, gotong royong masih tetap ada teturama dalam kehidupan sehari-hari. Namun, dalam hal pengolahan sagu setelah modernisasi telah berkembang Salah satu budaya gotong royong yang telah menghilang dapat dilihat dari persatuan masyarakat ketika salah satu pemuda desa akan menikah maka masyarakat akan bergotong royong mengolah sagu kemudian di jual, lau hasil penjualan digunakan untuk biaya pernikahan mulai dari uang panai hingga seluruh biaya pesta pernikahan. hasil penjualan sagu seluruhnya diberikan kepada pihak keluarga, yang dikeluarkan hanya harga pohon sagu jika pohon sagu bukan milik keluarga. Budaya tersebut telah luntur tergantikan oleh sistem upah . Sistem upah tetap merupakan sistem yang diterapkan dalam hubungan kerja, hal ini terjadi untuk memenuhi kebutuhan hidup keluarga para petani.

Untuk proses pengolahan sagu, mulai dari penebangan hingga pengemasan sagu, tidak ada tradisi yang dilakukan, tidak ada perlakuan istimewa terhadap proses pengolahan sagu karena sagu bukan tanaman yang dianggap memiliki nilai-nilai mistis serta proses tumbuh sagu yang mudah sehingga masyarakat tidak perlu melakukan penangannan khusus.

\section{b. Dampak Ekonomi \\ 1) Mata Pecaharian}

Mata pencaharian adalah keseluruhan kegiatan untuk mengeksploitasi dan memanfaatkan sumber daya yang ada pada lingungan fisik, sosial dan budaya yang terwujud sebagai kegiatan produksi, distribusi, dan konsumsi penduduk di Desa Cenning bermata pencaharian di sektor pertanian. Modernisasi menimbulkan dampak bagi kehidupan petani, dimana posisi mereka digantikan oleh perangkat mesin yang dijalankan oleh seorang yang ahli.

Di Desa Cenning penggunaan mesin untuk pengolahan sagu, membuat hasil produksi semakin meningkat sehingga membutuhkan banyak tenaga untuk melakukan produksi. Sebelum adanya mesin dalam mengolah sagu hanya membuthkan 2-3 orang saja yaitu pemarut, pemeras dan satu orang lagi yang bertugas mengangkat empulur sagu yang sudah diparut ke pinggir sungai untuk diperas jika jarak pohon sagu dan sungai jauh. Namun setelah menggunakan mesin proses produksi semakin cepat sehingga membutuhkan setidaknya 4-7 orang dalam satu kelompok kerja. Dalam satu kelompok kerja, mempunyai tugasnya dalam proses pengolahan di antaranya penebang batang sagu dilakukan dua orang, pembelah batang sagu, pemarut, dan penyiram. 
Tidak hanya kaum laki-laki yang berprofesi sebagai passampe, Semenjak permintaan sagu meningkat, permintaan olahan sagupun juga meningkat. Baik olahan makanan maupun olahan domestik seperti permintaan dange dan permintaan atap daun sagu atau bakkaweng. Dange merupakan salah satu olahan selain kapurung, dange juga banyak diminati karena beberapa alasan yang pertama kandungan karbohidratnya tinggi hampir setara dengan nasi dan kandungan gulanya lebih rendah dibanding beras. Kedua harga dange lebih murah jika dibandingkan dengan harga beras. Profesi pengolahan dange biasanya dilakukan oleh kaum wanita sama dengan pengolahan atap daun sagu, juga dikerjakan oleh wanita.

Permintaan atap daun sagu juga meningkat, permintaan ini banyak diperoleh dari luar Desa Cenning. Hampir setiap minggu para pengepul datang ke Desa Cenning untuk membeli Atap daun sagu yang telah di oleh kaum wanita untuk kemudian dijual lagi ke berbagai daerah seperti Lara, Masamba Sidrap dan Makassar. (Maslita, 2019). Jadi dalam satu keluarga, kaum laki-laki berprofesi sebagai passampe sedangkan kaum wanita berprofesi sebagai pengrajin atap daun sagu atau pembuat dange.

\section{2) Pendapatan Petani}

Modernisasi pengolahan sagu membawa dampak terhadap penghasilan petani sagu di Desa Cenning. Penghasilan petani perbulannya kurang lebih Rp. 3.000.000Rp. 5.000.000 perbulannya bagi pekerja biasa sedangkan bagi pemilik mesin, penghasilan perbulannya bisa Rp. 6.000.000Rp. 10.000.000 jika pemilik sagu juga ikut dalam proses pengolahan sagu. Dalam satu kali Sistem pembagian hasil dalam satu kelompok kerja dibagi rata dengan mengeluarkan terlebih dahulu harga batang sagu. Menurut Irwan sistem pembagian hasil di desa cenning dilakukan dengan dua cara:

\section{a) Pekerja Harian}

Untuk pekerja harian, mereka digaji Rp.100.000 per harinya oleh pemilik mesin. Maka ketika panjualan dilakukan gaji pekerja harian dikeluarkan terlebih dahulu sesuai berapa hari mereka bekerja serta harga dari batang sagu dikeluarkan. Setelah semua biaya produksi dikeluarkan maka pembagian upah di lakukan dengan cara membagi rata bagi kepada seluruh pekerja tetap. Jika yang bekerja tetap ada 3 orang maka pembagian hasil di lakukan dengan cara membagi 4 yaitu $25 \%$ untuk pekerja ke-1, 25\% untuk pekerja ke-2, $25 \%$ untuk pekerja ke-3 dan 25\% untuk pemilik mesin.

\section{b) Pekerja Tetap}

Untuk pekerja tetap, pembagian upah dilakuakan ketika penjualan sagu telah dilakukan. Sistem pembagian tetap sama, dengan terlebih dahulu mengeluarkan harga batang sagu yang telah diolah kemudian pembagian dilakukan misalnya pekerja berjumlah 4 orang maka pembagian hasil dilakukan dengan cara membagi 5 yaitu 20 $\%$ untuk pekerja ke-1, 20\% untuk pekerja ke-2, $20 \%$, untuk pekerja ke-4 dan 20\% untuk pemilik mesin. Untuk bahan bakar mesin baik mesin penggiling, mesin pompa air ataupun chain saw seluruhnya merupakan tanggungan pemilik mesin. (Arsyad, 2019) Penjualan dilakukan sebulan sebanyak dua kali, hal ini didasarkan dari besar kolam penampungan aci sagu, jika bak sudah penuh maka penjualan akan dilakukan. Untuk petani di Desa Cenning ukuran kolam penampungan diperkirakan untuk menampung aci selama sebulan. Satu karung sagu rata-rata seberat $50 \mathrm{Kg}$ dijual dengan harga Rp. 100.000-Rp. 120.000. Untuk karung yang digunakan untuk pembungkusan merupakan tanggungan pengepul yang diambil satu atau dua hari sebelum pembungkusan dilakukan. Dalam satu kali penjualan petani sagu mengemas kurang lebih 90 karung atau sekitar $4.500 \mathrm{Kg}$ sehingga rata-rata hasil dari penjualan mencapai Rp. 10.000.000.

Penghasilan petani dari pengolahan sagu tentunya udah mampu memenuhi kebutuhan sehari-hari bagi keluarga. Dari penghasilan tersebut, petani mampu mendirikan rumah, membeli motor, serta membiayai pendidikan anak-anak mereka meskipun membutuhkan waktu yang cukup 
lama untuk menabung. Dari penghasilan petani juga mampu membeli tanah atau salah satu kebiasaan petani sagu yaitu membeli pohon sagu yang masih kecil dengan harga yang lebih murah, untuk dipelihara hingga siap di olah menjadi aci sagu. harga satu pohon sagu yang masih kecil biasanya Rp. 50.000-Rp. 100.000, disesuaikan dengan umur pohon sagu. Bagi petani, seperti yang telah dibahas di atas bahwa istri-istri petani juga mengolah daun sagu menjadi atap rumah atau Bakkaweng yang kemudian dijual ke pengepul. Bakkaweng biasa dijual ke pengepul dengan harga Rp. 3.000 per lembar. Dalam satu minggu istri petani bisa menyelesaikan 300500 lembar. Hasil dari penjulan atap daun sagu ini biasanya ditabung untuk keperluan mendadak atau digunakan untuk kebutuhan sehari-hari jika mesin pengolah sagu sedang tidak beroperasi jika musim banjir datang. (Maslita, 2019).

\section{E. Kesimpulan}

Desa Cenning merupakan suatu daerah yang berada di wilayah administratif kabupaten Luwu utara. Desa Cenning sebagai desa dengan Luas lahan sagu terluas di Malangke Barat. Sebelum adanya modernisasi kehidupan masyarakat masih sederhana terutama dalam proses pengolahan sagu, petani masih bergantung pada alat-alat tradisional seperti sampe, balebbe, basong dan paru' serta masih menggunakan cara pengolahan yang terbelakang. Masuknya modernisasi pengolahahn sagu di Desa Cenning pada tahun 1982, yang di pelopori oleh Muh. Majid lalu kemudian secara perlahan diikuti oleh masyarakat. Ada teknologi memberikan keuntungan dan kemudahan dalam pengolahan sagu pengolahan menjadi lebih evektif dan efisien sehingga hasil produksi perlahan mengalami peningkatan dan berdampak pada perluasan jaringan pemasaran. Dalam penerapan modernisasi di Desa Cenning membawa dampak sosial budaya seperti dampak perubahan pola pikir, tenaga kerja dan dampak terhadap budaya gotong royong masyarakat. Di bidang ekonimi berdampak pada mata pencaharian dan pendapatan masyarakat petani

\section{DAFTAR PUSTAKA}

Arsyad, 2019. [Interview] (21 Maret 2019).

Bahri, S., 1995. Dampak Mekanisasi Pertanian Terhadap Kehidupan Masyarakat Petani di Kelurahan Benteng di Kelurahan Benteng, Kabupaten Sidenreng Rappang. Ujung Pandang: Balai Kajian Sejarah dan Nilai Tradisional.

Baso, 2019. [Interview] (23Maret 2019).

Batseba, M. W. T., 2000. Teknologi Peningkatan Produktifitas Ayam Buras, Jayapura: Loka Pengkajian Teknologi Pertanian Koya Barat.

Bayu Engal Rifikan, P. H. S., n.d. Modernisasi Pertanian (Studi Kasus Tentang Peluang Kerja dan Pendapatan Petani dalam Sistem Pertanian di Desa Dukuh Dempok. Volume I, p. 4.

Bustanul, A., 2001. Spektrum Kebijakan Pertanian di Indonesia. Jakarta: Erlangga.

Hadjosentono, M., 1979. mesin-mesin pertanian. Jakarta: Bumi Aksara.

Irwan, 2019. [Interview] (21 Maret 2019). Jumadil, 2019. [Interview] (20 maret 2019). Jurlis, 2019. [Interview] (21 Maret 2019).

Lisungan, J., 2012. Sagu Makanan Tradisional. Makassar: De Lamacca.

M Dien Madjid, J. W., 2014. IImu Sejarah Sebuah Pengantar. Jakarta: Prenada Media Group.

Madjid, A. R. H. d. M. S., 2018. Pengantar Ilmu Sejarah. Makassar: Reyhan Intermedia.

Masi', 2019. [Interview] (31 Mei 2019). Maslita, 2019. [Interview] (21 Maret 2019). Munthe, H. M., 2007. Modernisasi dan Perubahan Sosial Mayarakat dalam pembangunan Pertanian Suatu Tinjauan Sosiologi. Volume II, p. 4. 
Pangolangi, B. H. d. P., 1991. Potensi Sagu dan Pemanfaatan sagu. Yogyakarta: Kanisius.

Perkebunan, D. K. d., 2017. Kecamatan Malangke Barat dalam Angka, Luwu Utara: Dinas Kehutanan dan Perkebunan.

Reijentjes, C., 2014. Pertanian Masa Depan. Yogyakarta: Kanisius.

Sejarah, T. P. J. P., 2013. Pengantar Ilmu Sejarah. Makassar: Balai Penerbit UNM.

S, S., 2003. Sosiologi Umum. Bogor: IPB.

Suwondo, B., 1983. Sistem Gotong Royong dalam Masyarakat. Jakarta:

Departemen Pendidikan dan

Kebudayaan Daerah.

Syamsuddin, H., 2012. Metodologi Sejarah. Yogyakarta: Ombak. 
PATTINGALLOANG

CCJurnal Pemikiran Pendidikan dan Penelitian Kesejarahan

Volume 6 No.3 Juli-September 2019, 109-122|123 